Демиденко Иван

аспирант

ГОУ ВПО «Приднестровский государственный университет им. Т.Г. Шевченко»

г. Тирасполь, Республика Молдова

Вербина Анастасия

аспирант

ГОУ ВПО «Приднестровский государственный университет им. Т.Г. Шевченко»

г. Тирасполь, Республика Молдова

Ииимов Виктор канд. физ.-мат. наук, доцент ГОУ ВПО «Приднестровский государственный университет им. Т.Г. Шевченко» г. Тирасполь, Республика Молдова Белевский Станислав д-р философии в области химии Институт прикладной физики АНМ г. Кишинев, Республика Молдова

DOI $10.21661 / r-114533$

\title{
OPTIMIZATION OF GROWTH RATE OF THIN FILMS OF CADMIUM SULFIDE AT ELECTROCHEMICAL SEDIMENTATION
}

Аннотация: в данной работе показаны результаты исследования процесса осаждения сульфида кадмия из Аqие-ОЕ электролита. В рамках полного факторного эксперимента (FFE) математическая модель зависимости между средним катодным ростом скорости CdS пленок и условий осаждения был построен. Была продемонстрирована взаимосвязь между эффективностью тока и осаждения таких факторов, как рН, температуры и концентрации электролита. 
Ключевые слова: электрохимический синтез, полупроводниковых пленок, средний темп роста.

Abstract: the results of a study of the process of deposition of cadmium sulfide from an aqueous electrolyte were shown in this work. As part of the full factorial experiment (FFE), a mathematical model of dependence between the average speed growth cathode CdS films, and the deposition conditions was built. A relationship between current efficiency and deposition factors such as $p H$, temperature and electrolyte concentration was demonstrated.

Keywords: electrochemical synthesis, semiconductor films, average growth rate.

The composition of the films produced electrochemically deposition depends on the potential in which the synthesis is carried out. Therefore for the purpose of standardization of structure of the studied films, sedimentation was carried out in the potentsiostatic mode.

One of the major factors of defining composition of the films of $\mathrm{CdS}$, which were received by electrochemically sedimentation is electrodeposition potential. What causes expediency of use of the potentsiostatic mode of electrodeposition for receiving films of constant structure.

As show results cyclic voltammogram, at cadmium sulfide sedimentation from the electrolyte representing water solution of cadmium sulphate $\left(3 \mathrm{CdSO}_{4} \cdot 8 \mathrm{H}_{2} \mathrm{O}\right)$ and sodium thiosulfate $\left(\mathrm{Na}_{2} \mathrm{~S}_{2} \mathrm{O}_{3} \cdot 5 \mathrm{H}_{2} \mathrm{O}\right)$, process of cathodic allocation of $\mathrm{CdS}$ begins at potential - 0.74V (Rel. us. Ag/AgCl electrode) (fig. 1, point a). Limit current of this reaction is observed at the potential of $E=-0.76 \mathrm{~V}$ (fig. 1, point $\mathrm{b}$ ). The working potential on the recommendations given in [1], has been selected a potential corresponding to the middle of the reporting area, i.e. $\mathrm{E}=-0.75 \mathrm{~V}$.

Sedimentation, at cathodic potentials is lower than the potential of limit current of $\mathrm{E}=-0.8 \mathrm{~V}$ (fig. 1, point $\mathrm{c}$ ), leads to formation of conditions for joint sedimentation of sulfide of cadmium and metal cadmium what emergence of the second peak testifies, at anode dissolution of a deposit (fig. 1, point d) and that, therefore, involves violation of a stoichiometry of structure of an electrodeposit (film). 


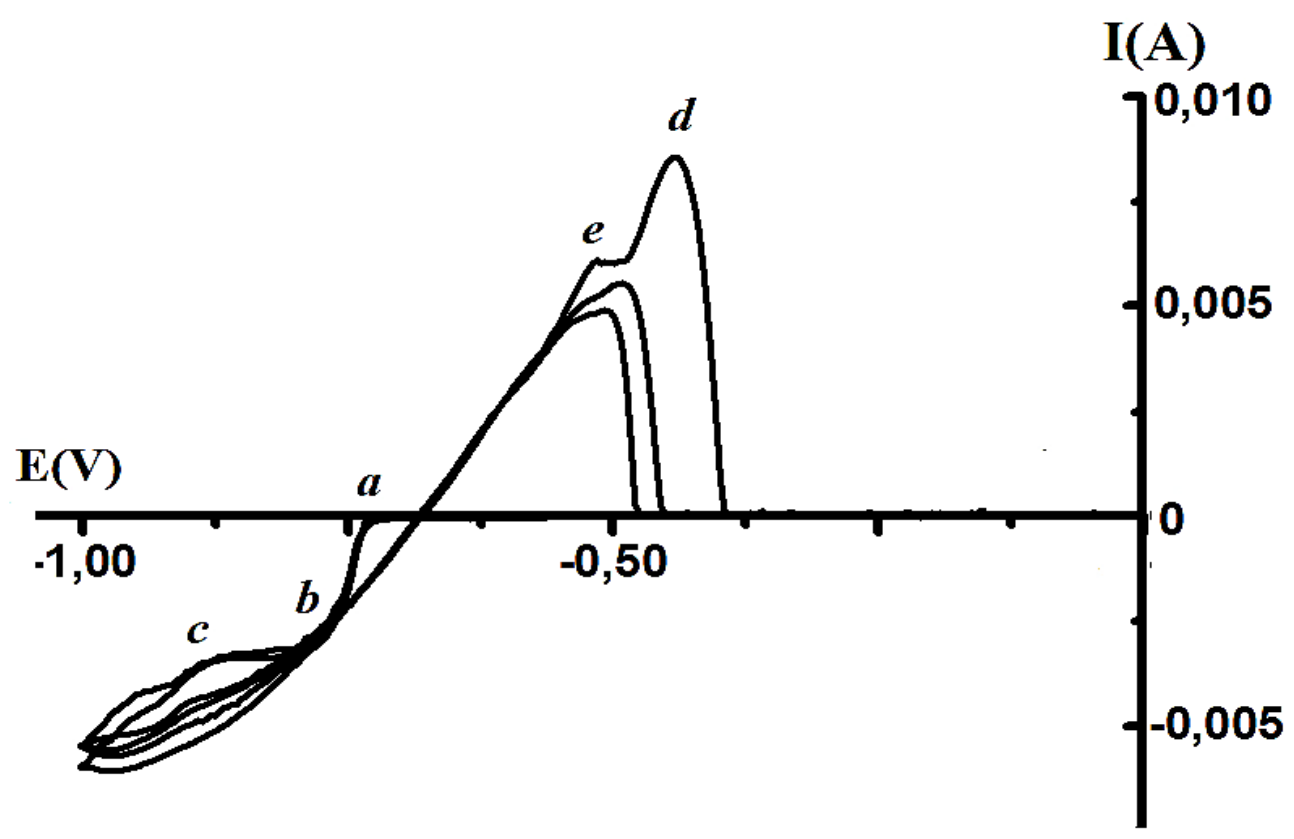

Fig. 1. Cyclic voltammogram of water solution $0,347 \mathrm{M} \mathrm{CdSO} 4$ and $0,347 \mathrm{M}$ $\mathrm{Na} 2 \mathrm{~S} 2 \mathrm{O} 3, \mathrm{pH}=2$, at a Pt electrode. Potential ramp rate $5 \mathrm{mV} \cdot \mathrm{s}-1$ : a -potential of reaction's beginning of cathodic sedimentation of CdS; b-potential site's beginning of limit current of sedimentation's reaction of CdS; c- potential of reaction's beginning of metal cadmium's sedimentation; $\mathrm{d}-$ the peak corresponding to process of joint etching of $\mathrm{CdS}$ and $\mathrm{Cd}$; e- peak corresponding to $\mathrm{CdS}$ etching process

The factors that affect the process of deposition films, such parameters were selected: the $\mathrm{pH}$ value; electrolyte temperature $(\mathrm{T})$; electrolyte concentration $(\mathrm{C})$.

Processing of experimental data was carried out by method, described in[2]. Within FFE technique, $k$ parallel series of experiments were conducted (where $k=1$, 2,3 ) at $g$ locations factorial space (where $g=1,2,3 \ldots 8$ ). Table 1 shows the combination of minimum and maximum values of the factors investigational factor space. In communication that calculations for a full factorial experiment uses normalized values, through $\mathrm{x}_{1}, \mathrm{x}_{2}, \mathrm{x}_{3}$ denote $\mathrm{pH}$, electrolyte temperature and concentration, respectively. Size $\mathrm{x}_{1}=+1$ corresponds to the value $\mathrm{pH}=6$, and the value $\mathrm{x}_{1}=-1$ corresponds to $\mathrm{pH}=1$. The value $\mathrm{x}_{2}=+1$ corresponds to $\mathrm{T}=85^{\circ} \mathrm{C}$, (the maximum temperature of the electrolyte in which the deposition was carried out), $\mathrm{x}_{2}=-1$ corresponds to $\mathrm{T}=25^{\circ} \mathrm{C}$, (the minimum temperature of the electrolyte). The value $x_{3}=+1$ corresponds to the concentration of 
$0,347 \mathrm{M} \mathrm{CdSO}_{4}$ and $0,347 \mathrm{M} . \mathrm{Na}_{2} \mathrm{~S}_{2} \mathrm{O}_{3}$, and $\mathrm{x}_{3}=-1$ corresponds to the concentration of $0,043 \mathrm{M} \mathrm{CdSO}_{4}$ and $0,043 \mathrm{M} \mathrm{Na}_{2} \mathrm{~S}_{2} \mathrm{O}_{3}$.

Table 1

Matrix of experimental design

\begin{tabular}{|c|c|c|c|c|c|c|c|c|c|c|c|}
\hline & & & & $\mathrm{Z}_{0}$ & $\mathrm{Z} 1$ & $\mathrm{Z} 2$ & $\mathrm{Z} 3$ & $\mathrm{Z} 4$ & $\mathrm{Z} 5$ & Z6 & $\mathrm{Z} 7$ \\
\hline $\mathrm{g}$ & $\mathrm{k} 1$ & $\mathrm{k}_{2}$ & $\mathrm{k} 3$ & $\mathrm{X} 0$ & $\mathrm{X} 1$ & $\mathrm{X} 2$ & $\mathrm{X} 3$ & $\mathrm{X} 1 \mathrm{X} 2$ & $\mathrm{X} 1 \mathrm{X} 3$ & $\mathrm{X} 2 \mathrm{X} 3$ & $\mathrm{X}_{1} \mathrm{X}_{2} \mathrm{X} 3$ \\
\hline 1 & 1 & 6 & 8 & +1 & -1 & -1 & -1 & +1 & +1 & +1 & -1 \\
\hline 2 & 7 & 5 & 4 & +1 & +1 & -1 & -1 & -1 & -1 & +1 & +1 \\
\hline 3 & 3 & 7 & 6 & +1 & -1 & +1 & -1 & -1 & +1 & -1 & +1 \\
\hline 4 & 8 & 2 & 7 & +1 & +1 & +1 & -1 & +1 & -1 & -1 & -1 \\
\hline 5 & 6 & 3 & 2 & +1 & -1 & -1 & +1 & +1 & -1 & -1 & +1 \\
\hline 6 & 4 & 4 & 1 & +1 & +1 & -1 & +1 & -1 & +1 & -1 & -1 \\
\hline 7 & 2 & 1 & 5 & +1 & -1 & +1 & +1 & -1 & -1 & +1 & -1 \\
\hline 8 & 5 & 8 & 3 & +1 & +1 & +1 & +1 & +1 & +1 & +1 & +1 \\
\hline
\end{tabular}

Thickness of the samples received during the experiment has been measured on a microscope of «МИИ-4».Based on the thickness of these films the average speed of growth was calculated for each test, and calculated the average speed of three parallel series of experiments, each of the 8 points of the test factor space (see table 2).

Table 2

Average speed film growth

\begin{tabular}{|c|c|c|c|c|c|c|}
\hline $\mathrm{g}$ & $\mathrm{V}_{1} \mathrm{~nm} / \min$ & $\mathrm{V}_{2} \mathrm{~nm} / \min$ & $\mathrm{V}_{3} \mathrm{~nm} / \min$ & $\overline{\mathrm{V}}$ & $\mathrm{S}_{\mathrm{g}(\text { dispersion })}^{2}$ & $\left(\overline{\mathrm{V}}-\mathrm{V}_{\text {mod }}^{\prime}\right)^{2}$ \\
\hline 1 & 0,49 & 0,96 & 0,54 & 0,66 & 0,06765 & 2,81 \\
\hline 2 & 0,02 & 0,02 & 0,02 & 0,02 & 0 & 2,81 \\
\hline 3 & 7,50 & 5,83 & 7,50 & 6,94 & 0,92593 & 2,81 \\
\hline 4 & 0,17 & 0,17 & 0,50 & 0,28 & 0,03704 & 2,81 \\
\hline 5 & 1,37 & 1,35 & 2,07 & 1,60 & 0,16783 & 2,81 \\
\hline 6 & 0,02 & 0,02 & 0,02 & 0,02 & 0 & 2,81 \\
\hline 7 & 3,03 & 2,80 & 4,67 & 3,50 & 1,03444 & 2,81 \\
\hline 8 & 2,08 & 3,83 & 1,80 & 2,57 & 1,20756 & 2,81 \\
\hline
\end{tabular}

The experimental results are tested for reproducibility by means of Cochran's criterion [2], which is based on the law of the distribution ratio of the maximum empirical variance to the sum of all variances. Then normalized values of the model in (1) was obtained:

$$
V_{\text {mod }}^{\prime}=-1.23 x_{1}+1.37 x_{2}-0.67 x_{1} x_{2}+0.6 x_{1} x_{3}-0.26 x_{2} x_{3}+0.83 x_{1} x_{2} x_{3}+1.95,(1)
$$

where $V^{\prime}$ mod is the mean rate of growth of films obtained by modeling using normalized values; $\mathrm{x}_{1}, \mathrm{x}_{2}, \mathrm{x}_{3}$. 
Applying the criterion of Fisher [2], it was confirmed by the adequacy of the model. That allowed us to obtain the equation (2) interprets the results of experiments in terms of named:

$$
\begin{aligned}
& V_{\text {mod }}^{\prime \prime}=0.022 \mathrm{X}_{1}+0.07 \mathrm{X}_{2}+3.78 \mathrm{X}_{3}-0.0095 \mathrm{X}_{1} \mathrm{X}_{2}- \\
& -0.63 \mathrm{X}_{1} \mathrm{X}_{3} 0.119 \mathrm{X}_{2} \mathrm{X}_{3}+0.026 \mathrm{X}_{1} \mathrm{X}_{2} \mathrm{X}_{3}-0.217
\end{aligned}
$$

where $\mathrm{V}$ «mod is the mean rate of growth of films obtained in the simulation with the use of the named variables; $\mathrm{X}_{1}, \mathrm{X}_{2}, \mathrm{X}_{3-}$ named values of $\mathrm{pH}$, temperature and electrolyte concentration, respectively.

The dependence described by the received equation, the average growth rate of a film from sedimentation conditions, is graphically presented in figure 2. As can be seen from this figure, in an acidic medium at $\mathrm{pH}=1$ the film growth is nearly three times more active than the electrolyte with $\mathrm{pH}=6$.

This results from the fact that in acidic environment there is a sodium thiosulphate decomposition on reaction [3]:

$$
\mathrm{Na}_{2} \mathrm{~S}_{2} \mathrm{O}_{3}+\mathrm{H}_{2} \mathrm{O}+\mathrm{H}_{2} \mathrm{SO}_{4} \rightarrow \mathrm{Na}_{2} \mathrm{SO}_{4}+\mathrm{S}+2 \mathrm{H}_{2} \mathrm{O}+\mathrm{SO}_{2} .
$$

This reaction is a sulfur source for formation reaction of $\mathrm{CdS}$.

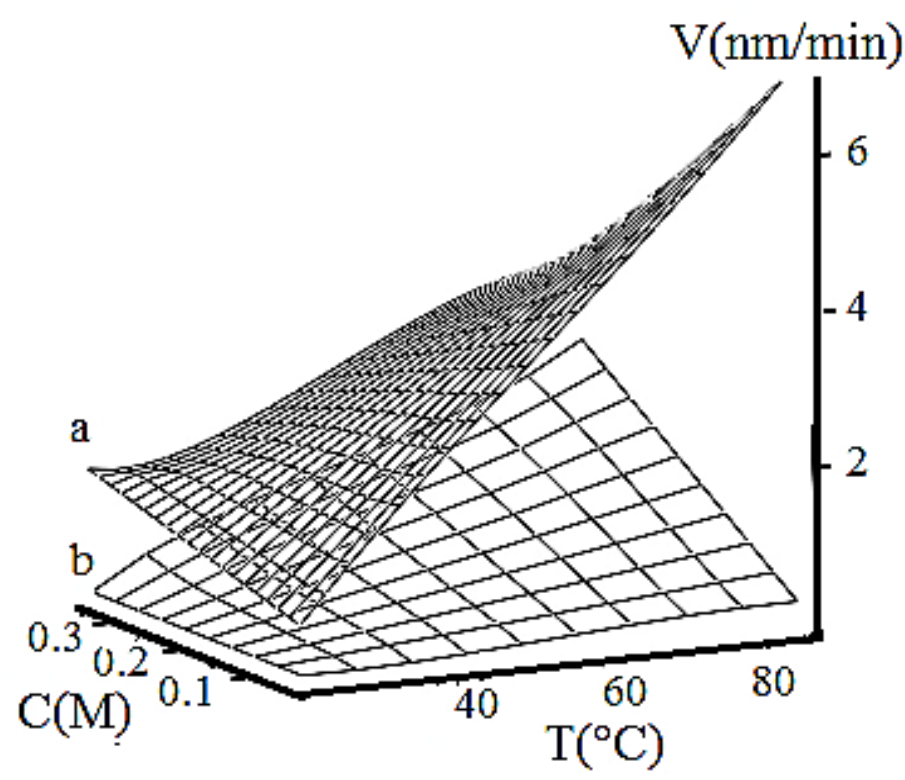

Fig. 2. Dependence of average growth rate of films on temperature and concentration of electrolyte: $\mathrm{a}-\mathrm{pH}=1 ; \mathrm{b}-\mathrm{pH}=6$ 
For the films obtained in the medium with $\mathrm{pH}=1$, the maximum growth rate is locate at high temperature and a low electrolyte concentration. Increasing the CdS film growth rate with increasing temperature of the electrolyte it can be explained by: first, an increase in the internal energy reserve of cadmium and sulfur ions, second diffusion growth on the cathode surface, and third acceleration of thiosulfate decomposition. In electrolyte with $\mathrm{pH}=6$ (fig. 2 , surfaceb), the maximum is located at high temperature and a combination with high electrolyte concentration. With decreasing operating temperature up to $25^{\circ} \mathrm{C}$, the rate of film growth tends to zero.

The results obtained in the experiments statistics were used to determine the dependence between the current efficiency an deposition process $\mathrm{CdS}$, and by deposition factors ( $\mathrm{pH}$, temperature, electrolyte concentration) As seen from figure 3, surface $a$, the maximum current efficiency is observed when using an acidic electrolyte with $\mathrm{pH}=1$, at low temperature and electrolyte concentration. With increasing temperature and concentration of the current output decreases. When using an electrolyte with $\mathrm{pH}=6$, the opposite pattern is observed (fig. 3 surface $b$ ), maximum current efficiency, is located in the high temperature and the concentration $\left(\mathrm{T}=85^{\circ} \mathrm{C} ; \mathrm{C}=0,347 \mathrm{M}\right)$. In the event of a given combination of temperature and concentration, the current efficiency decreases, tending to values less than $10 \%$.

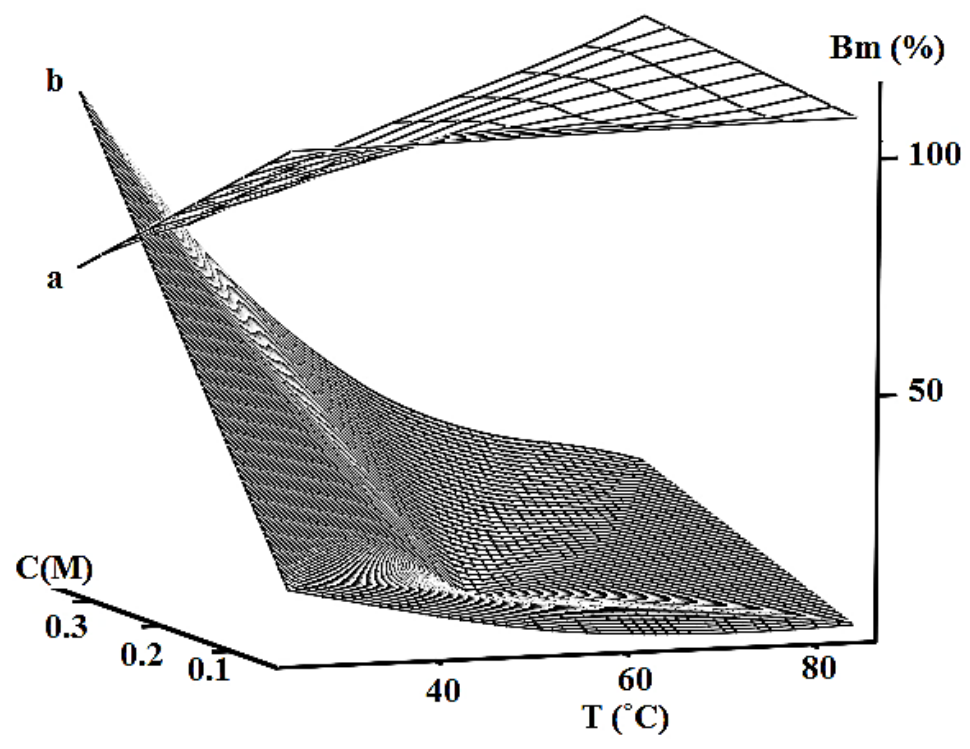

Fig. 3. Dependence of an current efficiency from temperature and concentration of electrolyte: $\mathrm{a}-\mathrm{pH}=1 ; \mathrm{b}-\mathrm{pH}=6$ 
A comparison of the average growth rate of the films, and the current efficiency of the deposition process, allows to select the optimal area of the factors for the synthesis of CdS films. For acidic electrolyte (fig. 4.1), the optimal ratio of the growth rate of current efficiency is observed at high temperatures and low electrolyte concentration, but in this case are grow the opaque films. Approximately the same structure have a film grown at a high temperature and high electrolyte concentrations, but in this case the growth rate is twice lower.
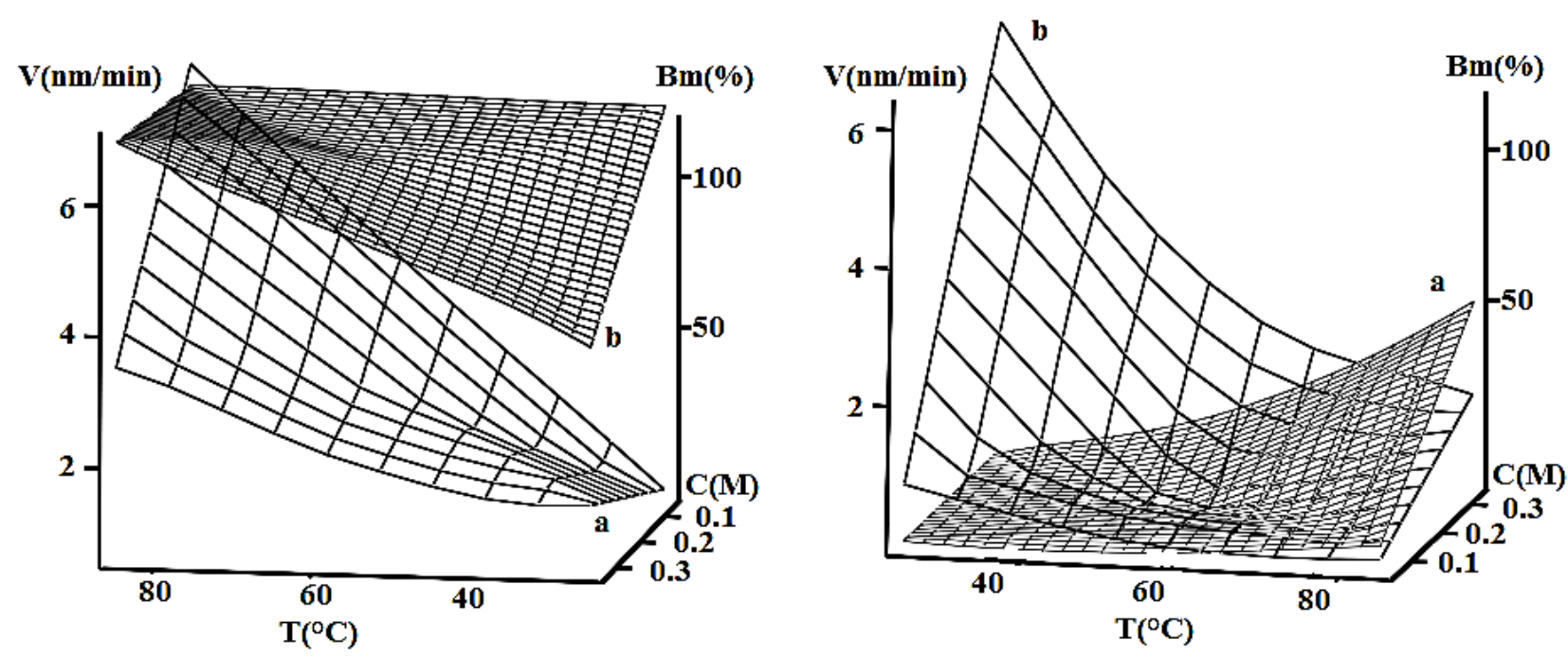

Fig. 4. Comparison of dependences of growth rate of films (a) and an current efficiency (b) from temperature and concentration of electrolyte: 1) $\mathrm{pH}=1$; 2) $\mathrm{pH}=6$

Conducting the synthesis at low temperatures leads to the formation of smooth surface films, both at high and at low electrolyte concentrations. Investigation of the transmission spectrum, allowed us to determine the width of the band gap of the synthesized material. Its value ranges from $2.3 \mathrm{eV}$-for films grown at $85^{\circ} \mathrm{C}$ to $2.45 \mathrm{eV}$ for the films obtained at $25^{\circ} \mathrm{C}$. What is near to the reference value of the width of the band gap at CdS 300K [4].

When using an electrolyte with $\mathrm{pH}=6$, a significant increase was observed only at elevated temperatures and high electrolyte concentration, in other cases only traces of CdS found on the cathode surface.

\section{References}

1. Гамбург Ю.Д. Теория и практика электроосаждения металлов / Ю.Д. Гамбург, Дж. Зангари // Теория. - М.: Бином, 2016. - 438 с. 
2. Долгов Ю.А. Статистическое моделирование: Учебник для вузов. 2-е изд., доп. - Тирасполь: Полиграфист, 2011. - С. 125.

3. Кульман А.Г. Общая химия. - изд. 3-е, перераб. и доп. - М.: Колос, 1979. $-528 \mathrm{c}$.

4. Шалимова К.В. Физика полупроводников. - М.: Энергия, 1976. - 416 с. 